\title{
Islamic Bank's Performance In The Light of Competition and CSR
}

\author{
Yunice Karina Tumewang \\ Universitas Islam Indonesia, Indonesia, yunice.karina@uii.ac.id \\ Novita Kusuma Maharani \\ Universitas Muhammadiyah Prof. Dr. Hamka, vhyta.maharani@gmail.com
}

Article History

Received: February 28, 2019 Revised: June 17, 2019 Accepted: July 8, 2018

\begin{abstract}
This study aims to examine the effect of competition and Corporate Social Responsibility (CSR) disclosure toward Islamic banks' financial performance. It used Generalized Least Square with panel data of Islamic Banks in ASEAN and GCC from 2012-2016 obtained from Orbis Bank Focus. H-Statistic (Panzar-Rosse) test was employed to measure the degree of competition and the relationship between variables. This study found that competition contributes a negative effect toward performance of Islamic banks, while CSR contributes a positive effect toward performance of Islamic banks. The result of this study suggests the management of Islamic banks to be more aware of the importance of management of CSR programs for the acceleration of SDGs set by UN as well as survival of companies in the future. Additionally, this study would like to support to push ahead government plan to strengthen domestic Islamic bank through consolidation or a merger of state-owned Islamic banks in order to lower the degree of competition which ultimately leads to a better performance of Islamic banks as well as an enhanced financial deepening in Indonesia.
\end{abstract}

Keywords: Competition, Islamic banks' performance, CSR disclosure JEL Classification: G20, G21, G28

@ IJIEF 2019 published by Universitas Muhammadiyah Yogyakarta, Indonesia All rights reserved

DOI:

Web:

https://doi.org/10.18196/ijief.2113

http://journal.umy.ac.id/index.php/ijief/article/view/5925

Citation:

Tumewang, Y. K., \& Maharani, M. K. (2019). Islamic Bank's Performance In The Light of Competition and CSR. International Journal of Islamic Economics and Finance (IJIEF), 2(1), 1-20. Doi: https://doi.org/ 10.18196/ijief.2113. 
Tumewang \& Maharani | Islamic Bank's Performance In The Light of Competition and CSR

\section{Introduction}

Islamic Banks which account for the largest chunk of Islamic finance industry is expected to contribute significantly to play a role as an alternative of financial system based on sharing-economy principle which could boost economic growth. Hence it becomes an important institution in world-wide financial sector. Average growth of Islamic Banking increased by $15-30 \%$ each year (Antonio et al. 2012). In this growth phase, performance measurement on Islamic Banking is necessary to be able to detect problems and settle concerns about the safety and soundness of investments for any stakeholders. Moreover, it can help the determination of banking prospect in the future to become better and sustainable Islamic Banking (Kuppusamy et al. 2010).

The climate changes of the banking sector in many countries has an impact on the level of competition and concentration of banks. There are two tendencies between competition and concentration which related inversely. These proportions reveal that the more concentrated market implicated the lower degree of competition due to unwillingness of the banks to have market power (Maharani \& Setiyono, 2018).The soundness and stability of the financial sector may in various ways be influenced by the degree of competition and concentration.

Competition can have a negative impact on stability because it can reduce bank charter value, so that can reduce the incentives for prudent risk-taking behavior. In previous literature, measuring the level of competition can examine using Non-Structural Approach based on New Empirical Industrial Organization (NEIO). This approach is based on premise that the company in a competitive and imperfect markets will have different reactions to the changes in demand and supply (Lubis, 2012). Thus, measuring competition is focused on price behavior and market power (World Bank Report, 2015) which are proxied by several methods such as H-Statistic, Lerner Index, and Boone Indicator.

$\mathrm{H}$-Statistics by Panzar-Rosse is a measurement to see the direct effect of bank competition based on market forces. H-Statistics is based on a market model that determines the balance of output by maximizing company-level profit and industry (Schaeck et. Al, 2012). Market Powetshows the performance of how much a company can raise prices above marginal costs. Companies that have high market power are considered as monopoly companies which are very affected by price changes.Meanwhile, companies that have low market power and are not affected by price changes (Lubis, 2012).

IJIEF: International Journal of Islamic Economics and Finance, 2(1), 1-20 |2 
Tumewang \& Maharani | Islamic Bank's Performance In The Light of Competition and CSR

On the other side, Islam respect on the good ethics and behavior which have brought into social justice, wealth, and maslahah as a way of life. So as in term of ethical individual and organizational in Islamic Banks environment that concern on "social good" and "good governance". As the form to create the ethical responsibilities in the Islamic Banks, Bank driven by public demand to increase transparency and accountability with regard social responsibility as a result of changes in community norms and expectations. CSR is a concession to Islam are meant for Islam as a religion show a proactive stakeholder paradigm and developing the company applying moral obligation to the community through substantive morality (Platonova et al. 2016).

Additionally, with regard to the stability of financial systems, poor corporate governance is considered to have negative affect and also have tangible, serious social and environmental consequences, the focus has shifted from the conventional 'shareholders only' approach to corporate governance to a broader corporate governance model that identifies the issues and priorities of stakeholders (Dusuki 2011). It means that company should take care of stakeholders' demands although they believe that CSR could connect to governance at the values level, determining the boundaries and accountabilities of the company in relation to a broad universe of stakeholders and its social and environmental responsibilities (Strandberg 2005).

There are many factors could be considered as the affecting variable on Islamic Bank's performance supported by a number of prominent literatures. This paper adds to the empirical literature of Islamic Bank's performance which relates to its competition in several ways.As far as we are concerned, there is only small number of researches on analyzing the competition of Islamic Banking such as Sghaier et al. (2015) and Mokhtar et al. (2008), although this kind of analysis is vital to improve the stability and development of this sector. This work is an attempt to fill in this gap. This study examines whether Islamic banks tend to be concentrated or even have a high level of competition. Besides, there is still several research that analyzes the impact of good corporate governance (GCG) policies. By applying CSR it is possible to increase the value of Islamic banks so that it affects the level of competition between banks. This study helps to raise the awareness of society to see Islamic Banking and its CSR's program as a mutually beneficial sector in the foreseeable future.

IJIEF: International Journal of Islamic Economics and Finance, 2(1), 1-20 |3 


\section{Literature Review}

\section{Islamic Bank’s Performance}

For many decades since its first footstep into the mainstream industry, Islamic finance has shown a slow progress despite its exponential growth in the first couple years. It has been widely criticized for just focusing on Islamic banking sector which are largely mimicking its counterpart with few 'controversial' distinctive values but undoubtedly higher cost. Though we have to be fair to say that many initiatives have been made by Islamic banks to upgrade its Sharia-compliance, but it still remains controversial in society.

Most studies in banking literature focused on profitability which affect on bank performances with generally used the financial ratio. Measuring the bank performance can be measured by internal and external factors. Ben and Omran (2011) analyzed the impact of bank regulation, concentration and institutional and financial development on the profitability of 173 banks in the MENA during the period 1988-2005. The empirical results suggest that the specific characteristics of banks, the capitalization of banks and especially credit risk, have a significant and positive impact on profitability, while indicators of macroeconomic and financial development have no significant impact on performance, with the exception of inflation. Ben and Rachdi (2014) assessing bank profitability in MENA region with the sample of 15 conventional and 15 Islamic banks. The result shows that the bank profitability in MENA region are slightly persistent due to the intervention of government that become barriers for banks to be more competitive.

\section{Previous Studies}

There are two tendencies between competition and concentration which related inversely. These proportions reveal that the more concentrated market implicated the lower degree of competition due to unwillingness of the banks to have market power. Other studies found that both competition and concentration can coexist. This term, refers to contestability theory assuming the company can enter or leave rapidly in the market without losing their capital and competitors have the same cost function as the companies that have been existing at these market (Mamatzakis et al. 2005). Efficiency is an important aspect to ascertain when evaluating the competition. Commonly, the more competitive market means the higher efficiency (Allen and Engert 2007). Another argument reveals that the greater competition among banks heading to more fragility (Beck et al. 2013).

Most studies in banking literature focused on profitability which affects

IJIEF: International Journal of Islamic Economics and Finance, 2(1), 1-20 |4 
banks' performance with generally used the financial ratio. Measuring the bank performance can be measured by internal and external factors. Ben Naceur and Omran (2011) analyzed the effect of bank regulation, concentration and institutional and financial development on the profitability of 173 banks in the MENA during the period 1988-2005. The result indicates that the specific characteristics of banks, the capitalization of banks and especially credit risk, have a significant and positive impact on profitability, whereas macroeconomic indicators and financial development have no significant impact on performance, with the exception of inflation. Mokni and Rachdi (2014) assessing bank profitability in MENA region with the sample of 15 conventional and 15 Islamic Banks. The result show that the bank profitability in MENA region are slightly persistent due to the intervention of government that become barriers for banks to more competitive.

Islam respect on the good ethics and behavior which have brought into social justice, wealth, and maslahah as a way of life. So as in term of ethical individual and organizational in Islamic Banks environment that concern on "social good" and "good governance". As the form to create the ethical responsibilities in the Islamic Banks, Bank driven by public demand to increase transparency and accountability with regard social responsibility as a result of changes in community norms and expectations. CSR is a concession to Islam are meant for Islam as a religion show a proactive stakeholder paradigm and developing the company applying moral obligation to the community through substantive morality (Platonova et al. 2016). Based on the above-mentioned literature review, the hypotheses developed in this study are as follow:

H1: Competition are negatively related to Islamic Banks' performance

H2: CSR weakening the negative relationship between Competition and Islamic Banks' performance.

\section{Research Method}

This study used yearly unbalanced panel method to identify the characteristic of each sample. Generalized Least Square (GLS) method was employed as a statistical technique to eliminate the problem of heteroscedasticity and autocorrelation, namely by weighting the value of its observations. Focusing on islamic and conventional commercial banks in 8 countries (Indonesia, Malaysia, Bahrain, Kuwait, Oman, Qatar, Saudi Arabia, and United Emirates Arab) were both bank types coexist, and the initial panel data set comprises a total of 314 banks (217 Islamic Banks and 97 Conventional Banks) with the period 2012-2016. The reason Conventional

IJIEF: International Journal of Islamic Economics and Finance, 2(1), 1-20 |5 
Tumewang \& Maharani | Islamic Bank's Performance In The Light of Competition and CSR

Banks to enter into the sample is to test directly the characteristics of Islamic Banks in each country that views of the whole banks. This paper takes bank specific information from Orbis Bank Focus database for banks variable and Thomson Reuters Datastream for CSR disclosure index.

This paper used H-Statistic adopting Panzar and Rosse test to examine directly the effect of bank competition based on market power, which is the sum of elasticities of the reduced-form revenue function with respect to factor prices (unit of capital, funds, and labor) (Schaeck et al, 2012). The result of H-statistic (Schaeck et. al, 2012; Bikker et. al, 2010; Mamatzakis et. al , 2005) can be interpreted as the characteristic of monopoly market colluding oligopoly perfectly when $\mathrm{H}$ is equal to 0 . Conversely if $\mathrm{H}$ is equal to 0 , it indicates a perfect competition market. Meanwhile, monopolistic competition condition can be indicated by the result of $\mathrm{H}$ between 0 and 1 .

CSR as a moderating variable is proxied by CSR disclosure index which is calculated as the ratio of points awarded over the total number of selected dimensions. The index is based on CSR categorization defined by 2010 AAOIFI Standards and items that are required and recommended by the Standards to disclose in annual reports of Islamic financial institutions, and also based on other established literatures. Some modifications were made to this checklist in order to adapt it to the conditions and characteristics of Islamic banks in the selected counties.

To calculate $\mathrm{H}$-Statistic, this paper use the specification of the reduced-form revenue equation (Mamatzakis et al, 2005; Schaeck et al, 2012) :

$$
\operatorname{Ln}(R)=\alpha+\beta 1 \operatorname{Ln}(w 1)+\beta 2 \operatorname{Ln}(w 2)+\beta 3 \operatorname{Ln}(w 3)+\delta 1 \operatorname{Ln}(y 1)+\delta 2
$$

$\operatorname{Ln}(y 2)+\varepsilon$

where $\mathrm{R}$ is proxied interest income to total asset (output price), w1 represents price of fixed asset (other operating expenses to fixed assets), w2 captures price of labour (staff expenses to total assets), and w3 captures price of funds (interest expenses to total liabilities). Respecting for risk and size, y1 denotes credit risk (impaired to NPL) and y2 is the proxy of total asset. Therefore, $\mathrm{H}$ is calculated as the sum of coefficient of $\beta 1+\beta 2+\beta 3$.

IJIEF: International Journal of Islamic Economics and Finance, 2(1), 1-20 |6 
Tumewang \& Maharani | Islamic Bank's Performance In The Light of Competition and CSR

CSR (moderating variable) is proxied by CSR disclosure index which is calculated as the ratio of points awarded over the total number of selected dimensions following Haniffa and Hudaib (2007):

$$
\text { CSR disclosure index }=\frac{\sum \sum_{i=1}^{n} x_{i j t}}{N}
$$

where CSR disclosure index jt denotes the CSR disclosure index for dimension $\mathrm{j}$ and period $\mathrm{t}$; Xijt is variable $\mathrm{X}(1, \ldots, \mathrm{n})$ for dimension $\mathrm{j}$ and time $\mathrm{t}$; $\mathrm{N}$ is the number of variables/statements.

The previous study expected that increased competition in the financial sector leads to boost efficiency and decreased the costs, but, in fact that financial product are quite heterogenous (Claessens and Laeven 2004).

Thus, the empirical model of this study based on relevant literature:

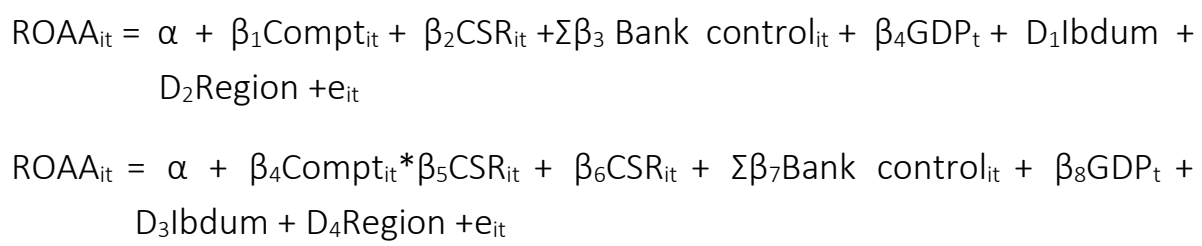

Where ROAArepresent return on average asset ratio is calculated by earning after tax (EAT) to total asset as a proxy of Islamic bank profitability, Compt denotes a competition of Islamic Banks which is measured by $\mathrm{H}$-statistic, CSR as a proxy of CSR disclosure index, $\Sigma$ bank control includes a set of bankspecific characteristics which is represented by Size (natural logarithm total asset), NPL (ratio of non-performing loan to total asset), and GDP is proxy for macroeconomic indicators which calculated by Gross Domestic Product (GDP) Growth. In addition, this paper includes a Islamic Banks dummy variable $\left(D_{1} \mid\right.$ bdum) to differ from Conventional Banks and regional dummy variable ( $D_{2}$ Region) to control for other region specific characteristics. Subscripts $i$ and $t$ refer correspondingly to Islamic Banks $i$ at time $t$, and e is a zero-mean disturbance term.

\section{Result and Analysis}

The paper first present the result of $\mathrm{H}$-statistic based on Panzar and Rosse test. In Table 1 are the results of the calculation of the H-statistic for each country the period of 2012 to 2016. These results cover the entire sample of Islamic Banks and Conventional Banks. The calculated of $\mathrm{H}$-statistics are in line with those reported by previous literatures and suggest that there is a monopolistic competition condition in both Islamic and Conventional Banks for each countries. Furthermore, in Table 2 are presented descriptive

IJIEF: International Journal of Islamic Economics and Finance, 2(1), 1-20 |7 
Tumewang \& Maharani | Islamic Bank's Performance In The Light of Competition and CSR

statistics of each variable. Table 3 shows correlation among variables which are in pairs. The test used to identify the correlation among the variables as indication of multicolinearity in independent variables.

Table 1. Summary Statistics of $\mathrm{H}$-statistic for Each Countries

This table report summary statistics of $\mathrm{H}$-statistic for each countries. This shows H-Statistic for the full sample of Islamic Banks and Conventional Banks.

\begin{tabular}{|c|c|c|c|c|c|c|c|c|}
\hline \multirow[b]{2}{*}{ Year } & \multicolumn{8}{|c|}{ Country } \\
\hline & Bahrain & Indonesia & Kuwait & Malaysia & Oman & Qatar & $\begin{array}{l}\text { Saudi } \\
\text { Arabia }\end{array}$ & UAE \\
\hline 2012 & $\mathrm{n} / \mathrm{a}$ & 0.75 & 0.58 & -0.23 & $\mathrm{n} / \mathrm{a}$ & $\mathrm{n} / \mathrm{a}$ & 0.47 & 0.71 \\
\hline 2013 & $\mathrm{n} / \mathrm{a}$ & 0.47 & 0.77 & 0.71 & 0.66 & -0.42 & 0.56 & 0.62 \\
\hline 2014 & -0.26 & 0.62 & 0.45 & 0.49 & 0.65 & 0.22 & 0.62 & $n / a$ \\
\hline 2015 & 0.13 & 0.66 & 0.3 & -0.76 & 0.6 & -0.64 & 0.59 & 0.11 \\
\hline 2016 & 0.89 & $\mathrm{n} / \mathrm{a}$ & $\mathrm{n} / \mathrm{a}$ & $n / a$ & $\mathrm{n} / \mathrm{a}$ & -0.1 & $\mathrm{n} / \mathrm{a}$ & 0.89 \\
\hline Average & 0.15 & 0.50 & 0.42 & 0.04 & 0.38 & -0.19 & 0.45 & 0.47 \\
\hline
\end{tabular}

In Table 4 (model $1,2,5,7$ ), $\mathrm{H}$-statistic as a proxied of competition have negatively affected on average return on asset (ROAA), indicating that the higher degree of competition will decrease banks' performance. This result suggest that the greater banks' performance have less competition. The result in line with competition and banks' profitability hypothesis, and banks with lower level of competition lead to higher concentration. According to the Competition-Fragility Paradigm, banks which have the higher degree of competition tend to reduce market power and decreased the profit margin. This result can also be concluded that most commercial banks in Indonesia have behavior that tends to be concentrated, even though the concentration level is still relatively low.

This result can also be attributed to the large number of foreign banks entering a country and the low restrictions on bank activities can encourage the level of competition in the banking system. Thus, concentrated banking is negatively related to competitiveness. The need for regulations regarding restrictions on the entry and exit of foreign banks into Indonesia can help guide the climate of effective competition and can also reduce gaps or imbalances that can affect the stability of the banking sector.

Under these circumstances, it is vital for the regulatory authorities to revisit the structuralchanges in order to avoid the occurrence of banking sector instability argued by theexisting literature. This research would like to push ahead the government plan to strengthen domestic Islamic bank through consolidation or a merger of state-owned Islamic banks in order to lower the degree of competition which ultimately leads to a better performance of Islamic banks in Indonesia.

IJIEF: International Journal of Islamic Economics and Finance, 2(1), 1-20 |8 
Tumewang \& Maharani | Islamic Bank's Performance In The Light of Competition and CSR

Indonesia's Islamic banking industry currently is highly fragmented, with 12 shariah-compliant commercial banks, 163 Islamic rural banks and 22 Islamic windows, and so, consolidation would likely bring significant economies of scale, therefore making the industry more competitive. All the usual arguments for bigger business and economies of scale appear on the surface to be relevant here, without the failings that might otherwise be relevant if we were truly looking at the creation of a megabank.

The merger of five state-owned Islamic banks which will include BNI Syariah, BRI Syariah, Bank Syariah Mandiri and the Shariah unit of BTN is expected to enhance financial inclusion as they will have more capital, more resources, and more offices across the country to offer more creative products and services to the customer. Together, these banks reportedly account for up to $40 \%$ of the Indonesian Islamic banking industry, and would create an entity with assets of US\$ 8 billion.

A mega Islamic bank will enable the Islamic banking industry to compete with larger conventional banks and to extend their financing to both SMEs and big corporate segment. Further, by having the big scale, mega Islamic bank could reduce operating costs and provide services at more competitive rates. It is also expected to help improving public awareness of shariahcompliant finance as well as having access and ability to raise further funding for large projects by issuing a series of sukuk (Islamic bonds) with a variety of maturities in diversified sectors and regions.

For having a smooth progress of Islamic banks' consolidation, sustained regulatory support and marketing of shariah-compliant financing, together with increased training and development of experts in the field will also be necessary for Islamic banks to achieve the OJK's desired aim of Islamic finance holding at least $15 \%$ of the Indonesian finance market by 2023 . The Indonesian authorities have made a promising start and shown a clear intention over the past 12 months to assist in shaping the way forward for the country's Islamic finance industry and in encouraging consolidation and proposals for building a new regulatory system.

This table shows descriptive statistics for dependent variable, banks' performance is proxied with the average of return on asset (ROAA), and independent variables this paper use in the regression that model ROAA as a function of competition, CSR, and a set of control variables. H-Statistic is the measure of competition, CSR as a moderating variable that is proxied with CSR disclosure index, the bank control variables are size (In asset) impaired to non performing loans, and GDP as a macroeconomic control variable. This paper report the number of observation, the mean, standard deviation, minimum and maximum.

IJIEF: International Journal of Islamic Economics and Finance, 2(1), 1-20 |9 
Tumewang \& Maharani | Islamic Bank's Performance In The Light of Competition and CSR

Table 2. Summary of descriptive statistic

\begin{tabular}{llllll}
\hline & Obs & Mean & St.Dev & Min & Max \\
\hline ROAA & 800 & 0.0125964 & 0.08786 & -0.02243 & 0.0366 \\
H-Statistic & 852 & 0.4052113 & 0.3942919 & -0.76 & 0.89 \\
CSR & 1171 & 62.44812 & 16.93912 & 23 & 96 \\
Size & 890 & 7.737923 & 0.8167508 & 5.245477 & 9.424317 \\
NPL & 815 & 13.79412 & 2.277882 & 6.116313 & 18.66686 \\
GDP & 956 & 0.0476198 & 0.0159576 & -0.01622 & 0.099589 \\
\hline
\end{tabular}

The result between $\mathrm{H}$-Statistic Interaction and Islamic Bank (H-Statistic * D_ibdum) is negative and not significant (Model 2 and 7). Based on these results, it can be concluded that Islamic banks cannot moderate competition relations and banks' performance. This shows that there is no difference in the effect of competition level on Islamic Bank and Conventional Banks on the performance of banks that correlate negatively. This finding implicates that the condition of firms at Islamic Bank is still low and does not reflect the performance of the Islamic Bank. These results are supported also by previous literature which found that Islamic banks have lower comparative rates compared to conventional banks (Ariss 2010).

The estimation result between ROAA and CSR is positive (Model 3, 4, 5, 6) indicates the existence of CSR is proven to improve bank performance. These results support previous literature where CSR implementation can have a positive impact on bank performance (Maqbool and Zameer, 2018; Odetayo et al. 2014). However, when CSR variables are witnessed with Islamic bank dummy (CSR * $D_{-}$ibdum) negative result is significant where the existence of CSR turns down the performance of sharia banks. This result is not in accordance with research found by Platonova et al (2016) in which CSR has a positive effect on bank financial performance.

Table 3. Pairwise Correlations Matrix

\begin{tabular}{lllllll}
\hline & ROAA & H-Statistic & CSR & SIZE & NPL & GDP \\
\hline ROAA & 1.00000 & & & & & \\
H-Statstic & -0.0646 & 1.00000 & & & & \\
CSR & -0.0612 & -0.0874 & 1.00000 & & & \\
SIZE & 0.3831 & -0.0092 & -0.3481 & 1.00000 & & \\
NPL & 0.2996 & -0.1541 & -0.3559 & 0.7562 & 1.00000 & \\
GDP & 0.0308 & 0.0843 & 0.2738 & -0.0423 & -0.0722 & 1.00000 \\
\hline
\end{tabular}


Tumewang \& Maharani | Islamic Bank's Performance In The Light of Competition and CSR

Further, this study attempted to interact with $\mathrm{H}$-Statistic and CSR (Model 6 and 7). The results show the value of negative and significant coefficients (Model 6) stating that CSR moderates the relationship of ROAA and $\mathrm{H}$ Statistic. There is a difference of influence between ROAA and H-Statistic moderated by CSR where CSR weakens the negative relationship between bank performance and competition. The presence of CSR can weaken the negative relationship between competition and bank performance. These results indicate that on the whole sample of competition level at banks implementing CSR will be higher.

This result is also supported by a research by Quairel-Lanoizele'e (2011) who concluded that the higher level of CSR, the competition negatively affects the banks' performance in the future because the CSR program is used by management as a form of entrepreneurs strategy to deal with stakeholders. This is due to management's expectations that competitiveness is not aligned with other stakeholders by implementing CSR programs. Then this research tried to interact with Islamic Bank dummy (H-Statistic * CSR * D_ibdum), but the result is not significant. So there is no difference in the effect of CSR moderation in Islamic banks and conventional banks.

Banks that are concerned about encouraging CSR programs have a good image in the public. Banks that focus on supporting the development of CSR programs will attract customer interest and increase bank performance. If there are banks that have implemented CSR programs, they will directly make other banks participate in developing CSR so as to increase the degree of bank competition. Thus, the competition climate will be created with the many banks that make up CSR programs. Finally, the bank's performance seen from its level of profitability will further increase bank profits. Even though many banks operate and go in and out in Indonesia which reflected high competition, it will not disturb its banks' performance.

The effect of size on banks' performance is positive and statistically significant at the 1 percent level on the overall model. StructuredConducted-Performance (SCP) hypothesis in which states that the larger banks in a more concentrated market will increase the banks' -charter values due to more profitable and high market power and would have more capital buffers (Chan et al. 2015). The influence of NPL is negative in value, indicating that banks with lower NPLs demonstrate better banks' performance that has lower loans and default risk.

While management cannot avoid opportunities for high-risk taking practices in boosting the financial performance, but the expected high-risk actions are not detrimental to the interests of other stakeholders in the long run so the banks can enjoy the benefits of CSR programs on the financial performance and in turn will be enjoyed by the public in general. Moreover, it will also link 
Tumewang \& Maharani | Islamic Bank's Performance In The Light of Competition and CSR

to the acceleration of United Nation's program stated in Sustainable Development Goals (SDGs) as they share equally a deep concern on environmental and social objectives among the society.

Table 4. Regression Result

\begin{tabular}{|c|c|c|c|c|c|c|c|}
\hline & $\begin{array}{c}(1) \\
\text { ROAA }\end{array}$ & $\begin{array}{c}(2) \\
\text { ROAA }\end{array}$ & $\begin{array}{c}(3) \\
\text { ROAA }\end{array}$ & $\begin{array}{c}(4) \\
\text { ROAA }\end{array}$ & $\begin{array}{c}(5) \\
\text { ROAA }\end{array}$ & $\begin{array}{c}(6) \\
\text { ROAA }\end{array}$ & $\begin{array}{c}(7) \\
\text { ROAA }\end{array}$ \\
\hline H-Statistic & $-0.0017^{*}$ & -0.001 & & & -0.001 & 0.009 & -0.000 \\
\hline H-Statstic*D_ibdum & $(0.001)$ & $\begin{array}{l}(0.001) \\
-0.002 \\
(0.002)\end{array}$ & & & $(0.001)$ & $(0.005)$ & $\begin{array}{l}(0.01) \\
-0.000 \\
(0.000)\end{array}$ \\
\hline H-Statistic*CSR & & & & & & $\begin{array}{l}-0.000^{*} \\
(0.000)\end{array}$ & $\begin{array}{c}-0.000 \\
(0.0002)\end{array}$ \\
\hline $\begin{array}{l}\text { H- } \\
\text { Statistic*CSR*D_ibdu }\end{array}$ & & & & & & & \\
\hline $\mathrm{m}$ & & & & & & & $\begin{array}{l}0.0001 \\
(0.000)\end{array}$ \\
\hline & & & $0.000 * *$ & $0.000^{* *}$ & $0.000^{* *}$ & & \\
\hline CSR & & & $\begin{array}{c}* \\
(0.000)\end{array}$ & $\begin{array}{c}* \\
(0.000)\end{array}$ & $\begin{array}{c}* \\
(0.000)\end{array}$ & $\begin{array}{c}0.000 * * * \\
(0.000)\end{array}$ & $\begin{array}{l}0.0001 \\
(0.000)\end{array}$ \\
\hline CSR*D_ibdum & & & & $\begin{array}{l}-0.000 \\
(0.000)\end{array}$ & & & $\begin{array}{l}-0.0002^{*} \\
(0.0001)\end{array}$ \\
\hline Size & $\begin{array}{c}0.0051^{* *} \\
*\end{array}$ & $\begin{array}{c}0.005^{* *} \\
*\end{array}$ & $\begin{array}{c}0.005^{* *} \\
*\end{array}$ & $\begin{array}{l}0.005^{* *} \\
*\end{array}$ & $\begin{array}{c}0.006^{* *} \\
*\end{array}$ & $\begin{array}{c}0.0052^{* *} \\
*\end{array}$ & $\begin{array}{c}0.004^{* *} \\
*\end{array}$ \\
\hline & $(0.001)$ & $(0.001)$ & $(0.000)$ & $(0.001)$ & $(0.001)$ & $(0.001)$ & $(0.000)$ \\
\hline NPL & $\begin{array}{c}-0.0001 \\
(0.000) \\
0.0731^{* *}\end{array}$ & $\begin{array}{c}-0.000 \\
(0.000) \\
0.070 * *\end{array}$ & $\begin{array}{l}-0.000 \\
(0.000)\end{array}$ & $\begin{array}{l}-0.000 \\
(0.000)\end{array}$ & $\begin{array}{l}-0.000 \\
(0.002)\end{array}$ & $\begin{array}{l}-0.000 \\
(0.000)\end{array}$ & \\
\hline GDP & $\begin{array}{c}* \\
(0.024)\end{array}$ & $\begin{array}{c}* \\
(0.024)\end{array}$ & $\begin{array}{l}0.040^{*} \\
(0.021)\end{array}$ & $\begin{array}{l}0.042^{* *} \\
(0.021)\end{array}$ & $\begin{array}{l}0.051^{* *} \\
(0.025)\end{array}$ & & $\begin{array}{l}0.061^{* *} \\
(0.026)\end{array}$ \\
\hline & $\begin{array}{c}- \\
0.0024 * *\end{array}$ & & $0.002^{-}$ & & & & \\
\hline D_ibdum & $*$ & -0.001 & $*$ & 0.001 & $-0.001 * *$ & $-0.002 * *$ & 0.008 \\
\hline & $(0.001)$ & $(0.001)$ & $(0.001)$ & $(0.002)$ & $(0.001)$ & $(0.001)$ & $(0.007)$ \\
\hline & & & $-{ }^{-}$ & $-{ }^{-}$ & $\begin{array}{c}- \\
0.002^{* *}\end{array}$ & & $-{ }^{-}$ \\
\hline D_Region & $\begin{array}{r}-0.0011 \\
(0.001)\end{array}$ & $\begin{array}{l}-0.001 \\
(0.001)\end{array}$ & $\begin{array}{c}* \\
(0.001)\end{array}$ & $\begin{array}{c}* \\
(0.001)\end{array}$ & $\begin{array}{c}* \\
(0.001)\end{array}$ & $\begin{array}{c}-0.002^{* *} \\
(0.001)\end{array}$ & $\begin{array}{c}* \\
(0.0001)\end{array}$ \\
\hline & - & - & - & - & - & & - \\
\hline c & $\begin{array}{c}0.0265^{* *} \\
* \\
(0.004)\end{array}$ & $\begin{array}{c}0.027^{* *} \\
* \\
(0.004)\end{array}$ & $\begin{array}{c}0.033^{* *} \\
* \\
(0.004)\end{array}$ & $\begin{array}{c}0.034^{* *} \\
* \\
(0.004)\end{array}$ & $\begin{array}{c}0.035^{* *} \\
* \\
(0.004)\end{array}$ & $\begin{array}{c}- \\
0.037^{* * *} \\
(0.005)\end{array}$ & $\begin{array}{c}0.032^{* *} \\
* \\
(0.006)\end{array}$ \\
\hline Obs & 560 & 560 & 641 & 641 & 560 & 579 & 598 \\
\hline No Banks & 196 & 196 & 196 & 196 & 196 & 197 & 212 \\
\hline
\end{tabular}


Tumewang \& Maharani | Islamic Bank's Performance In The Light of Competition and CSR

Full sample test of competition and banks' performance. The dependent variable is ROAA, which represents banks' performance. H-Statistic represents the competition among the banks. CSR as a moderating variable between competition and banks' performance. Size represents the natural logarithm of total bank assets. NPL is the proxy for bank risk. GDP is the annual growth of real gross domestic product. D_ibdum is an islamic bank dummy, and D_region as a dummy of banks' region.

GDP variables that represent macroeconomic conditions show positive and significant results in all models. Increased performance in banks was also an impact on improving a country's macroeconomic condition. According to the existing literatures, there is a huge gap found in the relationship between CSR disclosure, competition, and the macroeconomic view.

This paper examined the relationship between competition and performance of the bank, and then encounters competition with CSR and its effects on the performance of the bank. From the findings it can be concluded that based on previous literature, banks with high performance reflects the market power held by the bank. The amount of market power held by banks showed a dominant position in the market which leads to a high concentration. Thus, banks with high concentrations have low competition in the market. This study is also in line with concentrationstability theory in which a concentrated banking system more stable due to more profitable, better diversified, easier to monitor, and more resilient to shocks (Berger et al. 2003). This can trigger higher growth and greater access to the bank in carrying out its activities. The result show that the behavior of Islamic Banks are concentrated, due to the negative relationship between competition and performance of the bank which is interpreted by the high concentration for each countries.

However, this study proves that spending on CSR-related activities could weaken the negative correlation between competition and performance of Islamic Banks. For CSR approaches that adopt a new institutional grid of interpretation, corporate economic decisions should be embedded within a social network. Agreements among competitors in the same sector and also with other actors contribute to the institutionalisation of the values of sustainable development and to the definition of new market conditions according to generally accepted principles of international law or agreements which promote a broad vision of CSR. Overall, such agreements prefer cooperation to competition.

It is in line with Islamic worldview which encourages cooperation and social action. Islam emphasizes on the good ethics and behavior which have brought into social justice, wealth, and maslahah as a way of life. Therefore,

IJIEF: International Journal of Islamic Economics and Finance, 2(1), 1-20 |13 
Tumewang \& Maharani | Islamic Bank's Performance In The Light of Competition and CSR

Islamic banks environment should put more concern on "social good" and "good governance". As the form to create the ethical responsibilities in the Islamic banks, banks are driven by public demand to increase their transparency and accountability with the respect to social responsibility as a result of changing norms and expectations in society. "CSR is an intended consequence of Islamic ethics because Islam as a religion suggests a proactive and expanded stakeholders' paradigm through enforcing a moral obligation of corporations towards society by substantive morality" (Platonova et al. 2016).

The concern over CSR is also signerant to Islamic banks. As a business entity established within the scope of Islamic law (Shari'ah), Islamic banks are expected to be guided by an Islamic worldview, which is based on principle of social justice and wellbeing (Dusuki, 2006). This is particularly true since those involved in Islamic banking and ?nance normally regard their ethics and social responsibility commitment as being more enduring since they are ultimately based on divine revelation, whereas ethics and social responsibility derived from secularist morality are unavoidably temporary (Wilson, 2001)The concern over CSR is also significant to Islamic banks. As a business entity established within the scope of Islamic law (Shari'ah), Islamic banks are expected to be guided by an Islamic worldview, which is based on principle of social justice and wellbeing (Dusuki, 2006). This is particularly true since those involved in Islamic banking and Bance normally regard their ethics and social responsibility commitment as being more enduring since they are ultimately based on divine revelation, whereas ethics and social responsibility derived from secularist morality are unavoidably temporary (Wilson, 2001)

The concern over CSR is also significant to Islamic banks. As a business entity established within the scope of Islamic law (Shari'ah), Islamic banks are expected to be guided by an Islamic worldview, which is based on principle of social justice and wellbeing (Dusuki, 2006). This is particularly true since those involved in Islamic banking and ?nance normally regard their ethics and social responsibility commitment as being more enduring since they are ultimately based on divine revelation, whereas ethics and social responsibility derived from secularist morality are unavoidably temporary (Wilson, 2001)

The concern over CSR is also significant to Islamic banks. As a business entity established within the scope of Islamic law (Shari'ah), Islamic banks are expected to be guided by an Islamic worldview, which is based on principle of social justice and wellbeing (Dusuki, 2006). This is particularly true since those involved in Islamic banking and finance normally regard their ethics and social responsibility commitment as being more enduring since they are

IJIEF: International Journal of Islamic Economics and Finance, 2(1), 1-20 |14 
Tumewang \& Maharani | Islamic Bank's Performance In The Light of Competition and CSR

ultimately based on divine revelation, whereas ethics and social responsibility derived from secularist morality are unavoidably temporary.

The limits of the CSR concept within the liberal paradigm, arguing that the mainstream theoretical CSR framework based on the hypothesis of the convergence between firms' objectives and the common interest is not relevant. It can be explained by the paradox motivation of corporate conducting CSR merely torespond the increasing pressure from new social movements that denounce the irresponsible actions of large multinationals in the international context of deregulation, while the actual demand for CSR is low and the impact of this loss of legitimacy does not offset the pressures arising from strong global competition.

This paper highlights that the framework of Islamic worldview is more appropriate to analyze the identical link between CSR and competition in Islamic banks due to the presence of concept of mashlahah (benefit of the society) and maqashid sharia (purpose of Islamic rules). In the point of view of Islamic financial institutions, Islamic banks act not merely as an ordinary intermediary body, but also as a social agent which should manage the social funds for investment on real-sector activities which is highly Shariacompliant and socially-impactful.

\section{Conclusion \& Recomendation}

\section{Conclusion}

Based on hypothesis testing, this study could conclude that the competition has negative influence on the Islamic Bank's financial performance as the first hypothesis is accepted. In addition to that, as the second hypothesis is also accepted, it means that the activities of corporate social responsibility (CSR) associated with the degree of competition affect the company's financial performance in the future. Having said that, investors and creditors are expected to exercise careful consideration to the investment decision (the decision to provide loans), especially in manufacturing companies implementing CSR programs. Input for the management is expected to be more aware of the importance of management of CSR programs for the survival of companies in the future. To that end, management is expected to harmonize the various interests of stakeholders through CSR programs by maximizing the positive impacts and minimizing negative impacts of a particular business activity.

IJIEF: International Journal of Islamic Economics and Finance, 2(1), 1-20 |15 
Tumewang \& Maharani | Islamic Bank's Performance In The Light of Competition and CSR

\section{Recommendation}

Based on this empirical evidence, we would like to recommend regulatoryauthority to ensure a structure for the banking sector with necessary incentive forbanks, particularly for Islamic banks, to improve their profitability and efficiency. Nodoubt, a number of conversions to Islamic banking and various changes under financial deregulation have been successful in acceleratingthe level of competition. The issue is whether this changing level of competition canenhance the banking sector performance in a developing country like Indonesia. Suchdecision accelerates the competition level in the future, which may result in a decreasedperformance.

Under these circumstances, it is vital for the regulatory authorities to revisit the structural changes in order to avoid the occurrence of banking sector instability argued by the existing literature. This research would like to push ahead the government plan to strengthen domestic Islamic bank through consolidation or a merger of state-owned Islamic banks in order to lower the degree of competition which ultimately leads to a better performance of Islamic banks in Indonesia. The merger of five state-owned Islamic banks which will include BNI Syariah, BRI Syariah, Bank Syariah Mandiri and the Shariah unit of BTN is expected to enhance financial inclusion as they will have more capital, more resources, and more offices across the country to offer more creative products and services to the customer. A mega Islamic bank will enable the Islamic banking industry to compete with larger conventional banks and to extend their financing to both SMEs and big corporate segment.

For future research, we recommend to extend the period of observation as well as to have a broader coverage (include more Islamic banks in more selected countries not only the Muslim-majority country) for a more comprehensive result regarding the link between competition and CSR in Sharia-compliant banking industry.

IJIEF: International Journal of Islamic Economics and Finance, 2(1), 1-20 |16 
Tumewang \& Maharani | Islamic Bank's Performance In The Light of Competition and CSR

\section{References}

Allen, J., \& Engert, W. (2007). Efficiency and Competition in Canadian Banking. Bank of Canada Review. Summer 2007.

Beck, T., De Jonghe, O., \& Schepens, G. (2013). Bank competition and stability: Cross-country heterogeneity. Journal of Financial Intermediation. https://doi.org/10.1016/j.jfi.2012.07.001

Ben Naceur, S., Omran, M. (2011). The effects of bank regulations, competition, and financial reforms on banks' performance. EmergingMarkets Review 12, 1-20.

Ben Selma Mokni, R., \& Rachdi, H. (2014). Assessing the bank profitability in the MENA region. International Journal of Islamic and Middle Eastern Finance and Management, 7(3), 305-332. doi:10.1108/imefm-032013-0031.

Berger A. N., Kunt, A. D., Levine, R., \& Haubrich, J. G. (2003). Bank Concentration and Competition: An Evolution in the Making. Bank Concentration and Competition conferences. World Bank and Federal Reserve Bank of Cleveland.

Bikker, J., Spierdijk, L., \& Shaffer, S. (2010). Assessing Competiton with the Panzar and Rosse Model: The Role of Scale, costs, and Equiliriun. De Nederlansche Bank Working Paper. October 2009.

Chan, S., Koh, E., Zainir, F., \& Yong, C. (2015). Market Structure, Institutional Framework and Bank Efficiency in ASEAN-5. Journal of Economics and Business. 82 (2015). pp 84-112.

Claessens, S., \& Laeven, L. (2004). What Drives Bank Competition? Some International Evidence. Journal of Money, Credit, and Banking. Ohio State University Press. Vol 6. No. 3. pp 563-583.

Cornell, B., \& Shapiro, A. C. (1987). Corporate stakeholders and corporate finance. Financial Management, 16, 5-14.

Donaldson, T., \& Preston, L. E. (1995). The stakeholder theory of the corporation: Concepts, evidence, and implications. The Academy of Management Review, 20(1), 65-91.

Dusuki, A. W. (2011). Ethical and Social Responsibility Models for Islamic Finance. ISRA Research Paper.

Dusuki, A. W. (2011). Ethical and social responsibility models for Islamic finance. Research Paper No. 28/2011. International Shari'ah Research Academy for Islamic Finance (ISRA).

Françoise Quairel-Lanoizelée. (2011). "Are competition and corporate social responsibility compatible?: The myth of sustainable competitive advantage", Society and Business Review, Vol. 6 Issue: 1, pp.77-98, https://doi.org/10.1108/17465681111105850.

Freeman, R. E. (1984). Strategic management: A stakeholder approach. Boston: Pitman.

Haniffa, R., \& Hudaib, M. (2007). Exploring the ethical identity of Islamic Banks. Journal of Business Ethics, 76, 97-116.

Hellmann, T.F., Murdock, K.C., \& Stiglitz, J.E. (2000). 'Liberalization, moral 
Tumewang \& Maharani | Islamic Bank's Performance In The Light of Competition and CSR

hazard in banking, and prudential regulation: are capital requirements enough?', The American Economic Review, Vol. 90, No. 1, pp.147165.

Hughes, J. P., \& Mester, L. J. (1998). Bank capitalization and cost: Evidence of scale economies in risk management and signaling. Review of Economics and Statistics. https://doi.org/10.1162/003465398557401

Lubis, A. F. (2012). Market Power of Indonesian Banking. Bulletin of Monetary Economics and Banking, January 2012.

Maharani, N.K., \& Setiyono, B. (2018). Do Risk, Business Cycle, and Competition Affect Capital Buffer? An Empirical Study on Islamic Banking in ASEAN and MENA. Journal of Islamic Monetary Economics and Finance. Vol 3, No. 2 (2018), pp 181-200.

Mamatzakis, E., Staikouras, C., \& Koutsomanoli-Fillipaki, N. (2005). Competition and concentration in the banking sector of the South Eastern European region. Emerging Markets Review. https://doi.org/10.1016/j.ememar.2005.03.003

Maqbool, S., \& Zameer, M. N. (2018). Corporate social responsibility and financial performance: An empirical analysis of Indian banks. Future Business Journal. https://doi.org/10.1016/j.fbj.2017.12.002

Mokhtar, Hamim S., Ahmad., Naziruddin A., Syed M., \& Alhabshi. (2008). "Efficiency and competition of Islamic banking in Malaysia", Humanomics, Vol. 24 Issue: 1, pp.28-48, https://doi.org/10.1108/08288660810851450

Odetayo, T., Adeyemi, A., \& Sajuyigbe, A. (2014). Impact of Corporate Social Responsibility on Profitability of Nigeria Banks. International Journal of Academic Research in Business and Social Sciences. Vol. 4. August 2014. No. 8.

OJK. (2018). Roadmap pengembangan keuangan syariah 2017-2019. Otoritas Jasa Keuangan.

Platonova, E., Asutay, M., Dixon, R., \& Mohammad, S. (2016). The Impact of Corporate Social Responsibility Disclosure on Financial Performance: Evidence from the GCC Islamic Banking Sector. Journal of Business Ethics.

Preston, L. E., \& O'Bannon, D. P. (1997). The corporate social financial performance relationship: A typology and analysis. Business Society, 36, 419-429.

Schaeck, K., \& Cihák, M. (2012). Banking Competition and Capital Ratios. European Financial Management. https://doi.org/10.1111/j.1468036X.2010.00551.X

Sghaier, A., Lahdhiri, M., Gilles, P., \& Mansouri, F. (2015). Estimation of the Islamic Banks' Competitive Structure vs Conventional Banks' one. Global Journal of Management and Business Research, 15(7), 19-29.

Strandberg, C. (2005). The convergence of corporate governance and corporate social responsibility. Retrieved January 23, 2011 from http://corostrandberg.com/wpcontent/uploads/files/Corporate_Governance.pdf 
Tumewang \& Maharani | Islamic Bank's Performance In The Light of Competition and CSR

Suzuki, Y., \& Adhikary, B. K. (2010). 'A 'bank rent' approach to understanding the development of the banking system in Bangladesh', Contemporary South Asia, Vol. 18, No. 2, pp.155-173.

T.A, O., A. Z, A., \& A.S, S. (2014). Impact of Corporate Social Responsibility on Profitability of Nigeria Banks. International Journal of Academic Research in Business and Social Sciences. https://doi.org/10.6007/IJARBSS/v4-i8/1094

Yeyati, E. L., \& Micco, A. (2007). Concentration and foreign penetration in Latin American banking sectors: Impact on competition and risk. Journal of Banking and Finance. https://doi.org/10.1016/j.jbankfin.2006.11.003 
Tumewang \& Maharani | Islamic Bank's Performance In The Light of Competition and CSR

This page is intentionally left blank

IJIEF: International Journal of Islamic Economics and Finance, 2(1), 1-20 | 20 